\title{
Comparison of Effects of Using Geosynthetics and Lime Stabilization to Increase Bearing Capacity of Unpaved Road Subgrade
}

\author{
Erhan Burak Pancar ${ }^{1}$ and Muhammet Vefa Akpınar ${ }^{2}$ \\ ${ }^{1}$ Department of Architecture, Ondokuz Mayss University, Samsun, Turkey \\ ${ }^{2}$ Department of Civil Engineering, Karadeniz Technical University, Trabzon, Turkey \\ Correspondence should be addressed to Erhan Burak Pancar; erhanpancar@hotmail.com
}

Received 22 April 2016; Revised 21 July 2016; Accepted 1 August 2016

Academic Editor: Jianxi Zhu

Copyright (C) 2016 E. B. Pancar and M. V. Akpınar. This is an open access article distributed under the Creative Commons Attribution License, which permits unrestricted use, distribution, and reproduction in any medium, provided the original work is properly cited.

\begin{abstract}
So many soil improvement methods have been developed in order to increase bearing capacity of superstructure of the road to be constructed on the soft clayey road base soils, decrease settlements, and increase other strength specifications $\left(\mathrm{CBR}, k, M_{R}\right.$ values, etc.). In this paper, lime stabilization of clayey road base soil with high water content and its improvement with geosynthetics (geocell + geotextile) reinforcement and comparisons of these two different improvement methods were made. For this purpose, plate loading experimental comparisons of clayey soil, which had high water content by $10 \%$ increasing the optimum water content, were made after it was improved with lime at the rates of 3, 6, and 12\%, geotextile reinforcement, geocell reinforcement, geosynthetics reinforcement, and geosynthetics reinforcement + lime stabilization at various rates. It was understood that these improvement methods will not yield sufficient results on clayey soils with high water content on their own, and method of improvement with lime and then reinforcement with geosynthetics yields better results on these types of soils. Only one improvement state among ten different states examined in this study gave the sufficient results for the soil to be used for unpaved roads.
\end{abstract}

\section{Introduction}

Subgrade soils may safely withstand the stresses that traffic loads constitute. Soft soils have low shear strength and this causes excessive consolidation settlement and bearing capacity failure when they are used as a road subgrade. Bearing capacity of the soil is generally affected by soil type, water content, and compaction degree. The soils shall support high amount of loading without excessive settlement. It is required to stabilize the subgrade soils that are not appropriate for road superstructure by improving them. With the improvement of the soil, bearing capacity is increased, settlements are decreased, and therefore surfacing thickness is decreased and surfacing performance is increased. A variety of ground improvement techniques including vertical drains, complete soil replacement, grouting, geosynthetic reinforcement, and lime stabilization are used in several structures such as highways, railways, airports, and embankment to improve the performance of soils [1-6].

Many researchers have reported the ability of lime to change the plasticity of soils. The liquid limit of clay soil decreases when the lime content increases [7]. The plastic limit increases and the plasticity index which is the difference between the liquid limit and the plastic limit decreases with lime stabilization [8]. The $\mathrm{pH}$ becomes about 12.4 by mixing soil, lime, and water [9]. It is desired to get this $\mathrm{pH}$ value by adding lime to the soil and there is a minimum limit for lime content to achieve this goal. The strength of soil increases if the amount of lime added to the soil increases [10]. Dash and Hussain [2] determined that the optimum lime content was $9 \%$ for expansive soils and $5 \%$ for residual soilrich specimens.

Dash and Hussain [2] also stated that when the amount of lime added to the soil increases, the swell potential of soils 
decreases at first and then starts to increase after a certain limit of lime content. This content is $5 \%$ for fine-grained soils and $9 \%$ for coarse-grained soils. It is also known that excessive lime treatments decrease the soil strength. Because of that, calculating the optimum amount of lime is very important for lime stabilization.

Dash and Hussain [11] detected that the effect of lime on reducing the shrinkage potential of high plastic expansive soils is more than low plastic residual soil. The optimum lime content to get minimum shrinkage was calculated as $5 \%$.

In the studies, Kavak et al. [12] reviewed performance of lime stabilization of clay, with high plasticity, on the base soil of the real road. The necessary lime ratio was determined as $5 \%$. Implementation was done on total $40 \mathrm{~cm}$ part of the soil. The lime stabilization was applied in 2 layers as $20 \mathrm{~cm}$ for each. CBR (California Bearing Ratio) values increased from $11 \%$ to $56 \%$ after lime stabilization. At the plate loading experiments, maximum settlement decreased to $3.6 \mathrm{~mm}$ from $22.2 \mathrm{~mm} .8$ times increases occurred on dry CBR values of the material to which $5 \%$ lime was mixed at the end of 56 days and up to 34 times increases occurred on its wet CBR values compared to the natural material.

Geosynthetic reinforcement has been more used among soil improvement techniques. It gives an advantage of rapid construction at low costs. Zhou and Wen [13] have determined the mechanisms of geosynthetic reinforcement by explaining the confinement, pocket effect, raft foundation effect, and stress dispersion effect in their study.

Latha and Somwanshi [14] demonstrated that the geocell is the most advantageous form of geosynthetic reinforcement (i.e., geocell, planar layers, and randomly distributed mesh elements). Moghaddas Tafreshi and Dawson [4] and Dash et al. [15] also determined that geocell reinforcement is more desirable than planar reinforcement. Moghaddas Tafreshi and Dawson [4] stated that the geocell reinforcement improves the bearing capacity of soil more than $200 \%$ and reduces the settlement by $75 \%$.

Zhou and Wen [13] indicated that subgrade reaction coefficient $k_{30}$ can be improved by $3000 \%$, and the deformation can be reduced by $44 \%$ by using geocell-reinforced sand cushion. Sireesh et al. [16] and Dash et al. [15] stated that if a planar geogrid is added at the base of the geocell, the bearing capacity of the foundation also increases. Dash et al. [17] detected that this increasing can be $30 \%$ more than with geocell alone. The effect of planar reinforcement layer reduces by increasing the height of the geocell mattress.

The overall goal of this study was to demonstrate the benefits of geosynthetics reinforcement and lime stabilization for clayey pavement subgrade with high water content, with the detailed objective of this study being to compare the performance of geocell reinforcement, geotextile reinforcement, and lime stabilization by using these treatments solely and together. This comparison has not been made before in other studies.

\section{Cellular Confinement Systems}

As seen in Figure 1, cellular confinement systems (geocell, geoweb, neoweb, etc.) are a network having a high resistance

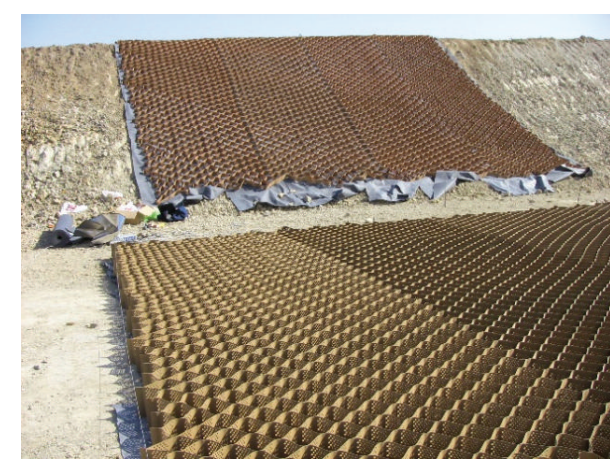

Figure 1: Application of geocell in the field.

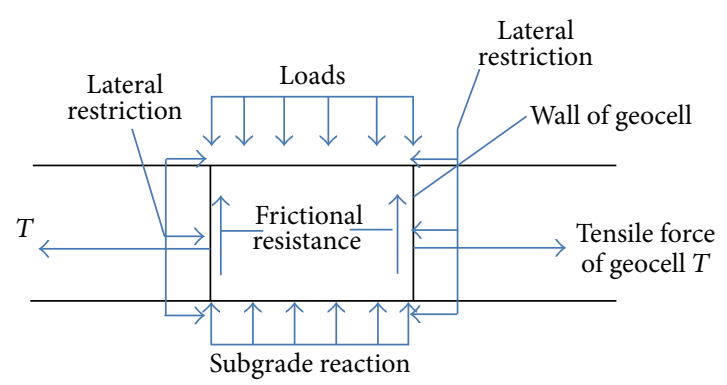

FIGURE 2: Lateral resistance effect of geocell reinforcement.

that was developed with the aim of stabilizing the soil by taking it under control and formed from three-dimensional cells interconnected with nodes in the shape of a honeycomb made from polyethylene. The cellular load bearing systems expand in the construction field and are filled with soil. The filling material completely covers the cell walls and confined the entire environment in the soil. Therefore, it increases load-deformation behavior and resistance of the soil by taking vertical loading stresses at the cell walls and soil resistance at the adjacent cells [18].

Zhao et al. [19] stated the working principle of geocell layer by explaining its three effects: lateral resistance effect, vertical stress dispersion effect, and membrane effect. Zhang et al. [6] explained these aspects in their study. Figure 2 shows the "lateral resistance effect" of geocell reinforcement. The soil above and below the geocell increases the lateral confinement and lower lateral strain.

Figure 3 shows the "vertical stress dispersion effect" of geocell reinforcement. Footing load is distributed over a wider area and the soil pressure decreases on the soft subgrade [6].

Figure 4 shows the "membrane effect" of geocell reinforcement. The loads deflect the geocell and it causes tension forces. The vertical component of the tension force is upward and it reduces the load and pressure on the subgrade soil [6].

In their study, Zhang et al. [6] determined that "vertical stress dispersion effect" and "membrane effect" are effective on increasing the bearing capacity of subgrade soil while "lateral resistance effect" of geocell reinforcement has no 


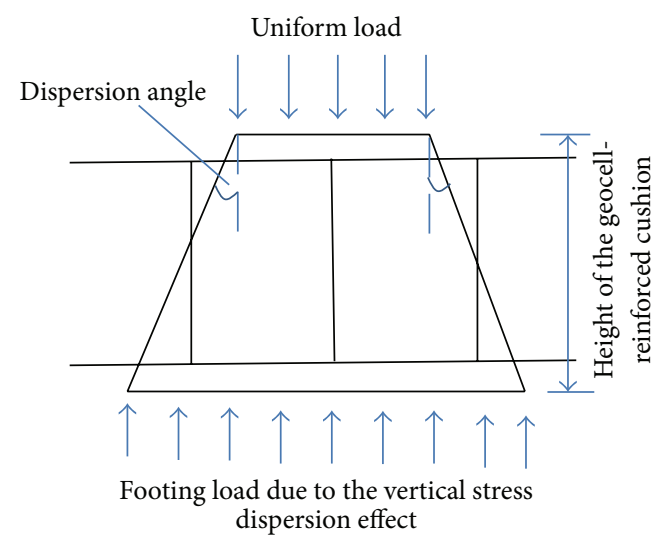

FIGURE 3: Vertical stress dispersion effect of geocell reinforcement.

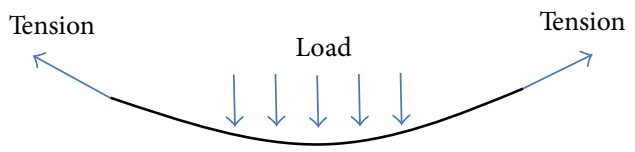

FiguRE 4: Membrane effect of geocell reinforcement.

significant effect. In that study, it is also observed that when the settlement is small, "vertical stress dispersion effect" is more effective than "membrane effect" and "membrane effect" is accepted as almost zero.

In that study, a different method from Koerner's method was used to draw bearing capacity increment-settlement $(\Delta p-s)$ curves. It was stated that $\Delta p$-s curve from the presented method in that study was more realistic than that from Koerner's method when the embankment settlement was larger than $5 \mathrm{~mm}$. This is because the influence of tension membrane effect of the reinforcement is not taken into account in Koerner's method. It was detected that dispersion angle has very significant effects on the calculated $\Delta p$-s curve and geocell size, infill material properties, and geocell tensional strength are effective on dispersion angle [6] although Dash et al. [17] stated that the tensile strength of the grid used to fabricate geocell mattress is not effective on geocell.

Dash et al. [17] stated that the footing width is important for pressure-settlement curve and this curve is almost linear up to settlement of half of the footing width. In their study, Moghaddas Tafreshi and Dawson [4] noted that in most of the researches settlement limit criterion is not taken into account and only bearing capacity is considered while dealing with the performance of footing. But settlement is very important in practical design of shallow foundations. The improvement in bearing capacity is estimated to be unreal in some studies $[15,17,20]$ because of not considering the acceptable range of settlement. The footing settlement $(s)$ must not be more than $12 \%$ of the footing width $(B)$. Using geotextile is very effective on reduction in footing settlement for higher settlements $(s / B>6 \%)[4]$.

\section{Material and Method}

3.1. Method. In this paper, experimental studies were conducted on clayey soil. After sieve analysis, consistency limit experiments and hydrometer analyses, respectively, were done on this material, which was classified according to AASHTO and unified soil classification system. In order to determine optimum water content and dry unit weight of the clay material, also modified proctor experiments were conducted. The experiments that were conducted up to here were done with the aim of determining class and specifications of the soil. In this paper, the experiment model that was mainly wanted to be conducted was plate loading experiment. With this aim, model plate loading experiments were conducted on the mixtures that were prepared from high water content (10\% more than optimum water content). In these experiments, the stabilization was done by the way the soil was reinforced with geocell and geotextile without adding anything to the clayey soil and lime was mixed to dry weight of the soil at the rates of 3,6, and $12 \%$ and high water content; in other words, natural water content of the soil was increased $10 \%$.

\subsection{Materials Used for the Testing}

3.2.1. Soil Used as a Subgrade and Sand Used as an Infill Material for Geocell. The sieve analysis of soil samples is shown in Table 1.

With the aim of classifying the material, consistency limits are given in Table 2. Measurements were made after 3 days' curing period of lime.

As per ASTM D2487 [21], the soil used as a subgrade was classified as clay with high plasticity (Class $\mathrm{CH}$ ).

The sand used as an infill material for geocell in this investigation was dry. It was used as a base layer for unreinforced test section. The effective particle size $\left(D_{10}\right)$ was $1.2 \mathrm{~mm}$, coefficient of uniformity $(\mathrm{Cu})$ was 2.25 , specific gravity was 2.64, and coefficient of curvature $(\mathrm{Cc})$ was 1.05. It is classified as poorly graded sand (SP) according to unified soil classification system [21]. The void ratio of the sand was 0.42 and internal friction angle was $37^{\circ}$.

3.2.2. Geosynthetics. The geocell and planar reinforcement used in this study were both made and supplied by the same company. The type of geotextile was nonwoven. The engineering properties of this geotextile, as listed by the manufacturer, are in Table 3.

The engineering properties of the geocell, as listed by the manufacturer, are in Table 4. There were also drainage holes having $10 \mathrm{~mm}$ diameter at geocell cell walls.

3.2.3. Lime. The chemical analysis information belonging to the lime used in this study is given in Table 5 .

\subsection{Model Plate Loading Experiment}

3.3.1. Experiment Tool. Laboratory model loading tests were conducted to compare the influence of geocell and geotextile 
TABLE 1: Wet sieve analysis.

\begin{tabular}{|c|c|c|c|c|}
\hline \multicolumn{5}{|c|}{ Sieve analysis } \\
\hline Sieve number & Sieve diameter $(\mathrm{mm})$ & Residue of sieving (gr) & Sieved (gr) & Sieved percent, $\%$ \\
\hline $3 / 8^{\prime \prime}$ & 9,53 & 0 & 420 & 100 \\
\hline 4 & 4,76 & 41,3 & 378,7 & 90 \\
\hline 10 & 2 & 29,6 & 349,1 & 83 \\
\hline 40 & 0,42 & 19,4 & 329,7 & 79 \\
\hline 100 & & 15,2 & 314,5 & 75 \\
\hline 200 & 0,074 & 12,7 & 301,8 & 72 \\
\hline Pan & & 301,8 & & \\
\hline
\end{tabular}

TABLE 2: Liquid limit and plastic limit experiments for natural soil and lime state.

\begin{tabular}{lccc}
\hline & \multicolumn{2}{c}{ Atterbeg (consistency) limits } \\
& Liquid limit & Plastic limit & Plasticity index \\
\hline Natural & 57 & 27 & 30 \\
$3 \%$ lime & 54 & 32 & 22 \\
$6 \%$ lime & 51 & 35 & 16 \\
$12 \%$ lime & 50 & 39 & 11 \\
\hline
\end{tabular}

TABLE 3: Technical properties of nonwoven geotextile.

\begin{tabular}{lc}
\hline Properties & Values \\
\hline Unit weight $\left(\mathrm{gr} / \mathrm{m}^{2}\right)$ & 500 \\
Thickness $(\mathrm{mm})$ & 4 \\
Tensile strength $(\mathrm{kN} / \mathrm{m})$ & $27-29$ \\
Breaking elongation $(\%)$ & $50-80$ \\
Static puncture resistance $(\mathrm{N})$ & 5500 \\
Dynamical puncture resistance $(\mathrm{mm})$ & 3 \\
Water permeability $(\mathrm{m} / \mathrm{sn})$ & 0.025 \\
Characteristic aperture size $(\mathrm{mm})$ & 0.1 \\
\hline
\end{tabular}

TABle 4: Technical properties of geocell.

\begin{tabular}{lc}
\hline Properties & Values \\
\hline Density $\left(\mathrm{gr} / \mathrm{cm}^{3}\right)$ & 0.94 \\
Welding size $(\mathrm{cm})$ & 40 \\
Cell length $(\mathrm{mm})$ & 300 \\
Cell width $(\mathrm{mm})$ & 250 \\
Thickness $(\mathrm{mm})$ & 2 \\
Cell depth $(\mathrm{cm})$ & 20 \\
\hline
\end{tabular}

reinforcement and lime stabilization on increasing the bearing capacity of clayey soil in a steel box. The overall inner dimensions of the box were $1.2 \mathrm{~m}$ length, $1.2 \mathrm{~m}$ width, and $1.2 \mathrm{~m}$ height as seen in Figure 5. Unpaved road test sections were constructed inside the box.

The pocket size $(d)$ of the geocell is taken as the diameter of an equivalent circular area of the pocket opening. This diameter was $25 \mathrm{~cm}$ in this study. Pocket diameter/footing width $(d / B)$ is reported by Dash et al. [15] to be around 0.8 times the footing width which is found to be the one that gives
TABLE 5: Chemical analysis of the lime (\%).

\begin{tabular}{lc}
\hline Chemical analysis & $\%$ \\
\hline $\mathrm{Ca}(\mathrm{OH})_{2}$ & $80-85$ \\
Active $\mathrm{CaO}$ & $60-65$ \\
Total $\mathrm{CaO}+\mathrm{MgO}$ & $85-95$ \\
$\mathrm{MgO}$ & $1-3$ \\
Density $(\mathrm{gr} / \mathrm{lt})$ & $375-500$ \\
\hline
\end{tabular}

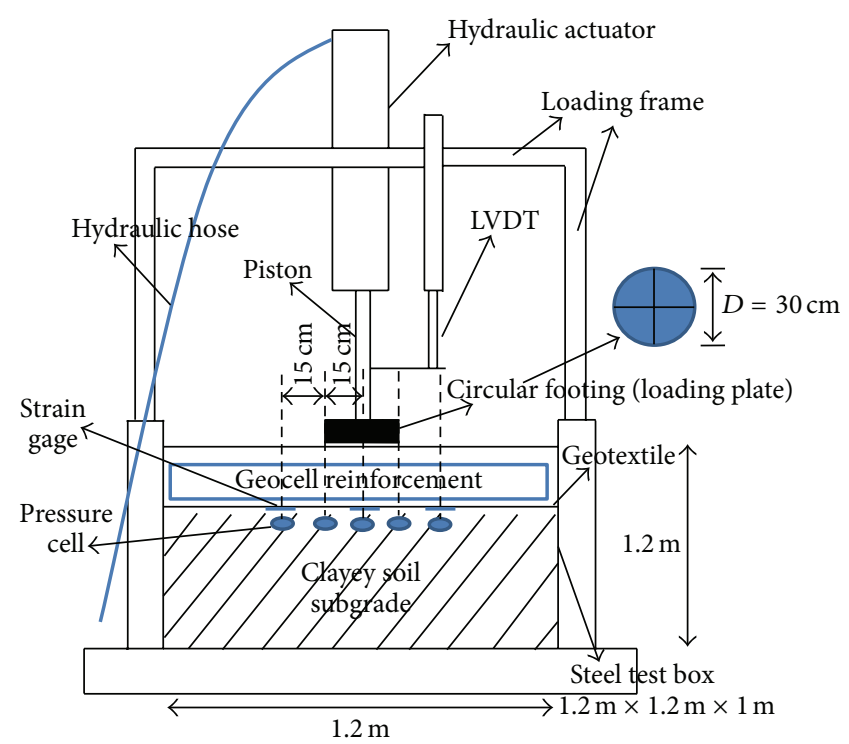

FIgURE 5: Schematic diagram for the set-up of the plate loading test.

maximum performance improvement. Due to this reason, the diameter of circular footing was determined as $30 \mathrm{~cm}$ in this experimental tool.

The footing was loaded with a hydraulic actuator and the circular footing was $30 \mathrm{~cm}$ in diameter and $3 \mathrm{~cm}$ thick. $1 \mathrm{~cm}$ thick rubber pad was attached to the bottom of the loading plate to ensure full contact and minimize stress concentrations at the edge of the plate. Dash et al. [17] detected that very good improvement in the footing performance can be obtained even with geocell mattress of width equal to the width of the footing and the optimum width of the geocell layer is around 4 times the footing width. Moghaddas Tafreshi and Dawson [4] determined that 
increasing the reinforcement width more than 4.2 times the footing width for the geocell would not provide much additional improvement in bearing pressure and additional reduction in footing settlement. Sireesh et al. [16] and Dash et al. [15] detected the efficient width of the geocell as 4.9 and 5 , respectively. In this experiment, geocell layer was chosen as 4 times the footing width. The peak load was selected to simulate a single wheel load of $40 \mathrm{kN}$ (equivalent to an axle load of $80 \mathrm{kN}$ and a tire contact pressure of $550 \mathrm{kPa}$ ).

The testing procedures in the experiment are as follows. The subgrade clayey soil was prepared by increasing the optimum water content of the clayey soil by $10 \%$ and bringing it to $35 \%$ outside the test device. The soil was mixed homogenously and represented a soil whose bearing capacity was low. The soil also stabilized by lime in proportions of 3,6 , and $12 \%$ by total weight of dry soil. The test box was filled with this soil at the depth of $75 \mathrm{~cm}$ as a subgrade. The subgrade soil was placed in 3 layers with $25 \mathrm{~cm}$ thickness for each layer. The placed layers were compacted in lifts inside a box using a vibratory plate compactor. The top of geocell mattress should be at a depth of 0.1 times the footing width from the bottom of the footing to obtain maximum benefit $[4,17]$. In this study, the top of geocell mattress was at a depth of $3 \mathrm{~cm}$ from the bottom of the footing.

After preparing the subgrade, three strain gages were installed on the top of the subgrade. Five pressure cells were installed on the surface of the subgrade at the center and $15 \mathrm{~cm}$ and $30 \mathrm{~cm}$ away from the center of the loading plate, respectively. A linear variable differential transducer (LVDT) was also placed on the footing model to provide the value of footing settlement during the loading (Figure 5).

Ten unpaved road test sections were prepared in the test box. Experiments were conducted on one (natural subgrade and unreinforced base), one (natural subgrade and geotextile reinforced base), one (natural subgrade and geocell-reinforced base), one (natural subgrade and geocell + geotextile reinforced base), three $(3,6$, and $12 \%$ lime stabilized subgrades and unreinforced bases), and three (3, 6, and $12 \%$ lime stabilized subgrades and geocell + geotextile reinforced bases) sections, respectively. Reinforced and unreinforced bases were all $23 \mathrm{~cm}$ thick. Unreinforced bases consisted of clayey soil. After installation of pressure cells and strain gages, a layer of geotextile was placed on top of the subgrade and the geocells were placed on top of geotextile for reinforced sections. The geocell used in this experiment was $20 \mathrm{~cm}$ thick, top of the geocell mattress was at a depth of $3 \mathrm{~cm}$ from the bottom of the footing, and the geocell width was $1.18 \mathrm{~m}$ as Moghaddas Tafreshi and Dawson [4] and Dash et al. [17] detected the ratios between footing width, geocell height, and geocell width to get optimum test results.

\section{Results and Discussion}

4.1. Load-Deformation Findings and Review. Comparison between the improvement of clayey unpaved road subgrade with geosynthetics and lime stabilization was made in the laboratory. Ten different alternatives for road sections were

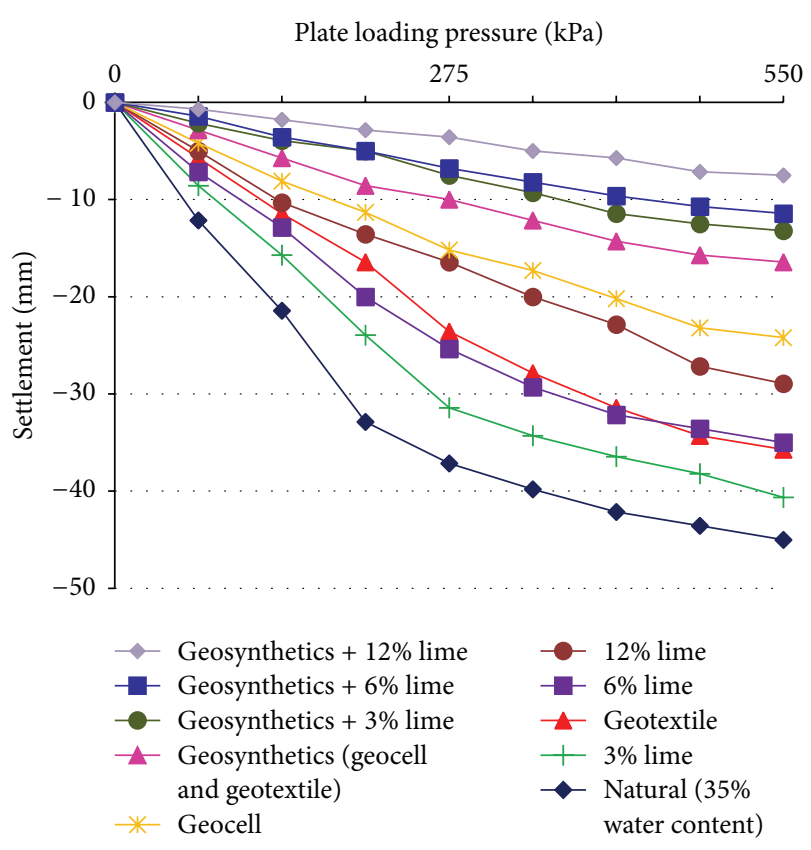

FIGURE 6: Loading-settlement curve.

examined in this study. The loading-settlement relation at different states is in Figure 6. While the maximum settlement in natural state at $550 \mathrm{kPa}$ pressure was $45 \mathrm{~mm}$, this settlement was decreased to $41 \mathrm{~mm}$ when soil was stabilized with $3 \%$ lime, $36 \mathrm{~mm}$ when soil was reinforced with geotextile, $35 \mathrm{~mm}$ when soil was stabilized with $6 \%$ lime, $29 \mathrm{~mm}$ when soil was stabilized with $12 \%$ lime, $24 \mathrm{~mm}$ when soil was reinforced with geocell, $16 \mathrm{~mm}$ when soil was reinforced with geosynthetics (geocell + geotextile), $13 \mathrm{~mm}$ when soil was reinforced with geosynthetics (geocell + geotextile) and subgrade was stabilized with $3 \%$ lime, $11 \mathrm{~mm}$ when soil was reinforced with geosynthetics (geocell + geotextile) and subgrade was stabilized with $6 \%$ lime, and $8 \mathrm{~mm}$ when soil was reinforced with geosynthetics (geocell + geotextile) and subgrade was stabilized with $12 \%$ lime. It was observed that the effects of geotextile (placed $23 \mathrm{~cm}$ under the top surface of the soil) and lime stabilization of soil with $6 \%$ lime were similar to each other. The settlement at geotextile reinforcement state was 1.5 times the geocell reinforcement state and 2.1 times the geosynthetics reinforcement under $550 \mathrm{kPa}$ loading. The settlement at natural state was 6 times the settlement at geosynthetics $+12 \%$ lime state under the same loading. The authors in [4] stated that the value of footing settlement that equals $12 \%$ of footing width is considered absolute upper limit. It was observed that four states (natural, 3\% lime, geotextile, and 6\% lime) among ten states examined in this study did not meet the requirements of settlement.

4.2. Modulus of Subgrade Reaction. The most popular model in determining the modulus of subgrade reaction $(k)$ is Winkler model. In this model, the subgrade soil is assumed to behave like infinite number of linear elastic springs such that the stiffness of the spring is named as the modulus 
TABLE 6: Modulus of subgrade reaction.

\begin{tabular}{lc}
\hline States & $\begin{array}{c}\text { Modulus of subgrade } \\
\text { reaction }(k)\left(\mathrm{kN} / \mathrm{m}^{3}\right)\end{array}$ \\
\hline Natural & 6.765 \\
$3 \%$ lime & 9.677 \\
$6 \%$ lime & 12.000 \\
Geotextile & 12.608 \\
12\% lime & 15.000 \\
Geocell & 18.330 \\
Geosynthetics & 26.000 \\
Geosynthetics $+3 \%$ lime & 42.000 \\
Geosynthetics $+6 \%$ lime & 48.300 \\
Geosynthetics $+12 \%$ lime & 70.000 \\
\hline
\end{tabular}

of subgrade reaction. The direct method to estimate the modulus of subgrade reaction is plate load test that is done with $30-100 \mathrm{~cm}$ diameter circular plate or equivalent rectangular plate.

Modulus of subgrade reaction values was calculated with the help of Figure 6 by determining the inclinations of loading-settlement curves. These values are listed in Table 6 .

As seen in Table 6 , " $k$ " value was $6765 \mathrm{kN} / \mathrm{m}^{3}$ for natural state of the soil which had $35 \%$ water content and this value was $70.000 \mathrm{kN} / \mathrm{m}^{3}$ for soils reinforced with geocell + geotextile and $12 \%$ lime stabilized. According to Highways Technical Specifications in Turkey, this value is to be no less than $55.000 \mathrm{kN} / \mathrm{m}^{3}$ and "geosynthetics $+12 \%$ lime" was the only state that met the requirement of Highway Technical Specifications. It was seen that lime stabilization or reinforcement with geosynthetics solely did not meet the requirement of modulus of subgrade reaction in this study. The only acceptable situation was making geosynthetics reinforcement after stabilizing soil with $12 \%$ lime. Although Dash and Hussain [2] determined that, for expansive soil dominant samples, the optimum lime content was $9 \%$, in this study $12 \%$ lime content was the better proportion among 3,6 , and $12 \%$ lime treatments. In Figure 7 , the relation between the modulus of subgrade reaction and ratio of lime used to stabilize the soil is seen. In Figure 8, the relation between the modulus of subgrade reaction and geosynthetics reinforcement with lime content in the soil is seen.

4.3. Vertical Stress. Vertical stresses occurring on the subgrade soil were measured by the help of pressure cells used in the experiment. These values were measured at $23 \mathrm{~cm}$ lower than the bottom of the loading plate and they are seen in Figure 9. It is detected that geosynthetics reinforcement is more effective than $12 \%$ lime stabilization. $12 \%$ lime stabilization + geosynthetics reinforcement is much more effective than the other states. The stress value, $23 \mathrm{~cm}$ lower and at the center of the plate, of natural soil is about 2.5 times the stress value obtained at $12 \%$ lime stabilization + geosynthetics reinforcement.

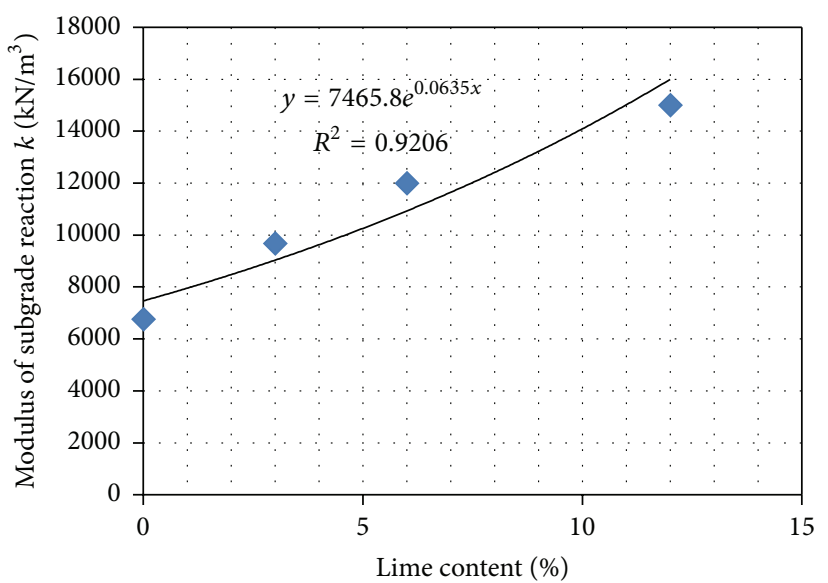

FIGURE 7: Modulus of subgrade reaction with respect to lime content in the soil.

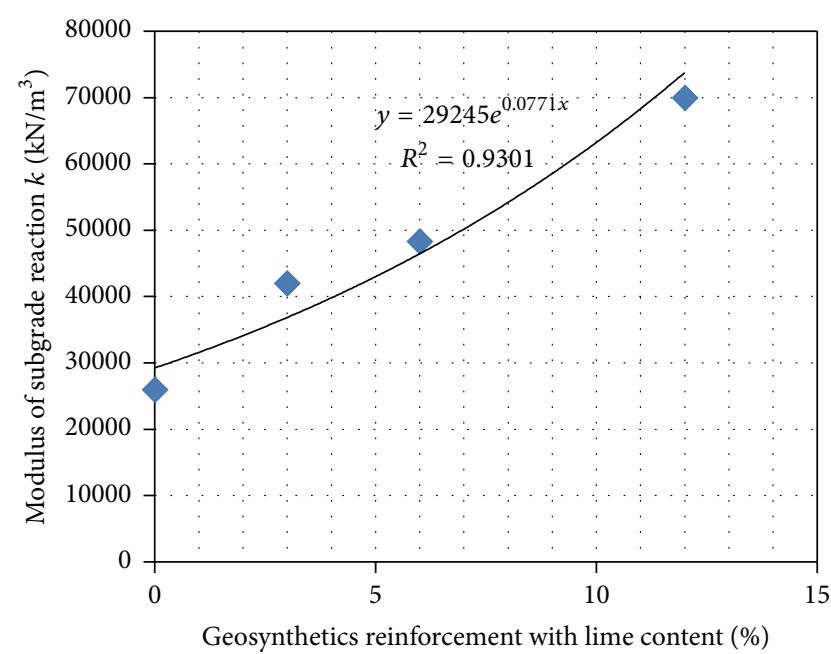

FIGURE 8: Modulus of subgrade reaction with respect to geosynthetics (geocell + geotextile) reinforcement with lime content in the soil.

\section{Conclusion}

In this paper, the effects of lime stabilization, geotextile reinforcement, geocell reinforcement, geosynthetics (geocell + geotextile) reinforcement, and lime stabilization + geosynthetics reinforcement were researched for unpaved road which has clayey subgrade with high water content. Model plate loading experiments were done in the laboratory for this purpose. Comparisons of these soil improvement methods were made. These comparisons have not been made before in the literature for ten different states examined in this study. This study is important to detect the optimum soil improvement method among lime stabilization, geocell, and geotextile reinforcement for unpaved roads with clayey subgrade which has high water content. Plate loading test was made by considering optimum dimensions obtained from other studies. 


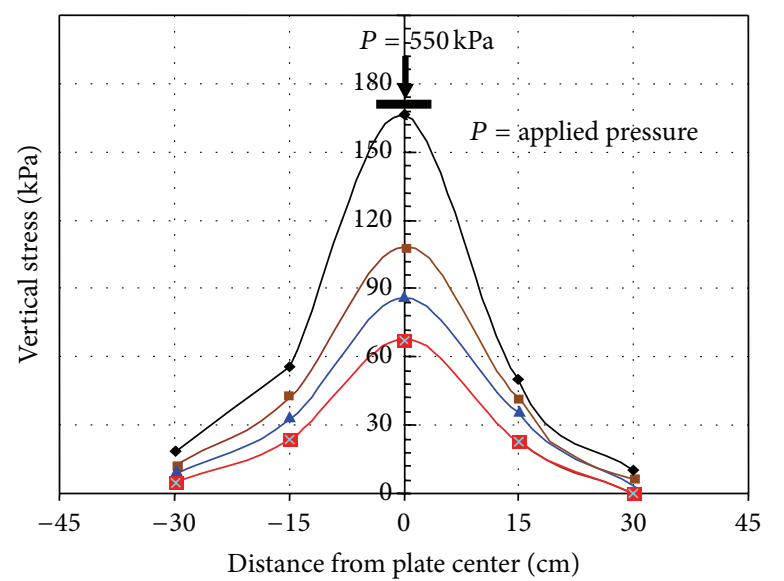

$\begin{array}{ll}\rightarrow & \text { Unreinforced soil } \\ \rightarrow & 12 \% \text { lime }+ \text { geotextile }+ \\ \text { geocell reinforcement } & -12 \% \text { lime stabilized }\end{array}$

Figure 9: The vertical stress values on subgrade.

As a result of plate loading test, lime stabilization achieves decrease in soil settlement. $12 \%$ lime stabilization gave better results among 3,6, and $12 \%$ lime treatments for reduction of settlements. Although lime stabilization or geotextile reinforcement decreases settlements, natural clayey soil with high water content (10\% more than optimum content), 3 and $6 \%$ lime stabilization, and geotextile reinforcement did not meet the settlement requirement which must be at most $12 \%$ of the width of footing. $12 \%$ lime stabilization, geocell reinforcement, geosynthetics reinforcement, and geosynthetics reinforcement + lime stabilization gave the sufficient values for settlement among ten states in this study. Geosynthetics reinforcement $+12 \%$ lime stabilization was the best treatment to get lowest settlement and it was 5.6 times the settlement at natural state under $550 \mathrm{kPa}$ loading pressure. The stress value measured at $23 \mathrm{~cm}$ lower than the bottom of the loading plate for natural state was 2.5 times the stress value obtained at $12 \%$ lime stabilization + geosynthetics reinforcement.

Lime stabilization and geosynthetics reinforcements all increased the modulus of subgrade reaction $(k)$. But when the natural clayey soil, which has $35 \%$ water content by increasing the optimum water content of the clayey soil by $10 \%$, has " $k$ " value of $6765 \mathrm{kN} / \mathrm{m}^{3}$, only one state (geosynthetics $+12 \%$ lime stabilization) among 10 states applied to improve the soil in this experiment met the Highways Technical Specifications with a value of $70.000 \mathrm{kN} / \mathrm{m}^{3}$.

When clayey soil with high plasticity (Class $\mathrm{CH}$ ), with $10 \%$ more water content than optimum water content, is used as an unpaved road base, it does not meet the bearing capacity and modulus of subgrade reaction requirements. Lime stabilization or geosynthetics reinforcements are not enough on their own for this purpose. It is recommended to stabilize the soil with $12 \%$ lime content and then reinforce it with geotextile and geocell to improve these types of soils to be used for unpaved roads.

\section{Competing Interests}

The authors declare that they have no competing interests.

\section{References}

[1] A. Wilkinson, A. Haque, J. Kodikara, J. Adamson, and D. Christie, "Improvement of problematic soils by lime slurry pressure injection: case study," Journal of Geotechnical and Geoenvironmental Engineering, vol. 136, no. 10, pp. 1459-1468, 2010.

[2] S. K. Dash and M. Hussain, "Lime stabilization of soils: reappraisal," Journal of Materials in Civil Engineering, vol. 24, no. 6, pp. 707-714, 2012.

[3] N. R. Krishnaswamy, K. Rajagopal, and G. Madhavi Latha, "Model studies on geocell supported embankments constructed over a soft clay foundation," Geotechnical Testing Journal, vol. 23, no. 1, pp. 45-54, 2000.

[4] S. N. Moghaddas Tafreshi and A. R. Dawson, "Comparison of bearing capacity of a strip footing on sand with geocell and with planar forms of geotextile reinforcement," Geotextiles and Geomembranes, vol. 28, no. 1, pp. 72-84, 2010.

[5] S. Y. Liu, J. Han, D. W. Zhang, and Z. S. Hong, "A combined DJM-PVD method for soft ground improvement," Geosynthetics International, vol. 15, no. 1, pp. 43-54, 2008.

[6] L. Zhang, M. Zhao, C. Shi, and H. Zhao, "Bearing capacity of geocell reinforcement in embankment engineering," Geotextiles and Geomembranes, vol. 28, no. 5, pp. 475-482, 2010.

[7] F. G. Bell, "Lime stabilization of clay minerals and soils," Engineering Geology, vol. 42, no. 4, pp. 223-237, 1996.

[8] J. E. Barker, C. D. F. Rogers, and D. I. Boardman, "Physiochemical changes in clay caused by ion migration from lime piles," Journal of Materials in Civil Engineering, vol. 18, no. 2, pp. 182-189, 2006.

[9] J. K. Mithchell and K. Soga, Fundamentals of Soil Behavior, John Wiley \& Sons, Hoboken, NJ, USA, 3rd edition, 2005.

[10] N. C. Consoli, L. Lopes Jr., P. Prietto, L. Festugato, and R. Cruz, "Variables controlling stiffness and strength of limestabilized soils," Journal of Geotechnical and Geoenvironmental Engineering, vol. 137, no. 6, pp. 628-632, 2011.

[11] S. K. Dash and M. Hussain, "Influence of lime on shrinkage behavior of soils," Journal of Materials in Civil Engineering, vol. 27, no. 12, Article ID 04015041, pp. 1-9, 2015.

[12] A. Kavak, A. G. Güngör, C. Avşar, B. Atbaş, and A. Akyarlı, "A lime stabilization application on a divided road project," in Zemin Mekaniği ve Temel Mühendisliği Onikinci Ulusal Kongresi, Selçuk University, Konya, Turkey, October 2008.

[13] H. Zhou and X. Wen, "Model studies on geogrid- or geocellreinforced sand cushion on soft soil," Geotextiles and Geomembranes, vol. 26, no. 3, pp. 231-238, 2008.

[14] G. M. Latha and A. Somwanshi, "Effect of reinforcement form on the bearing capacity of square footings on sand," Geotextiles and Geomembranes, vol. 27, no. 6, pp. 409-422, 2009.

[15] S. K. Dash, S. Sireesh, and T. G. Sitharam, "Model studies on circular footing supported on geocell reinforced sand underlain by soft clay," Geotextiles and Geomembranes, vol. 21, no. 4, pp. 197-219, 2003.

[16] S. Sireesh, T. G. Sitharam, and S. K. Dash, "Bearing capacity of circular footing on geocell-sand mattress overlying clay bed with void," Geotextiles and Geomembranes, vol. 27, no. 2, pp. 8998, 2009. 
[17] S. K. Dash, N. R. Krishnaswamy, and K. Rajagopal, "Bearing capacity of strip footings supported on geocell-reinforced sand," Geotextiles and Geomembranes, vol. 19, no. 4, pp. 235-256, 2001.

[18] A. Emersleben and N. Meyer, "Bearing capacity improvement of gravel base layers in road constructions using geocells," in Proceedings of the 12th International Conference of International Association for Computer Methods and Advances in Geomechanics (IACMAG '08), pp. 3538-3545, Goa, India, October 2008.

[19] M.-H. Zhao, L. Zhang, X.-J. Zou, and H. Zhao, "Research progress in two-direction reinforced composite foundation formed by geocell reinforced mattress and gravel piles," China Journal of Highway and Transport, vol. 22, no. 1, pp. 1-10, 2009.

[20] S. G. Thallak, S. Saride, and S. K. Dash, "Performance of surface footing on geocell-reinforced soft clay beds," Geotechnical and Geological Engineering, vol. 25, no. 5, pp. 509-524, 2007.

[21] ASTM, "Standard practice for classification of soils for engineering purposes (unified soil classification system)," Tech. Rep. D2487, ASTM, West Conshohocken, Pa, USA, 2006. 

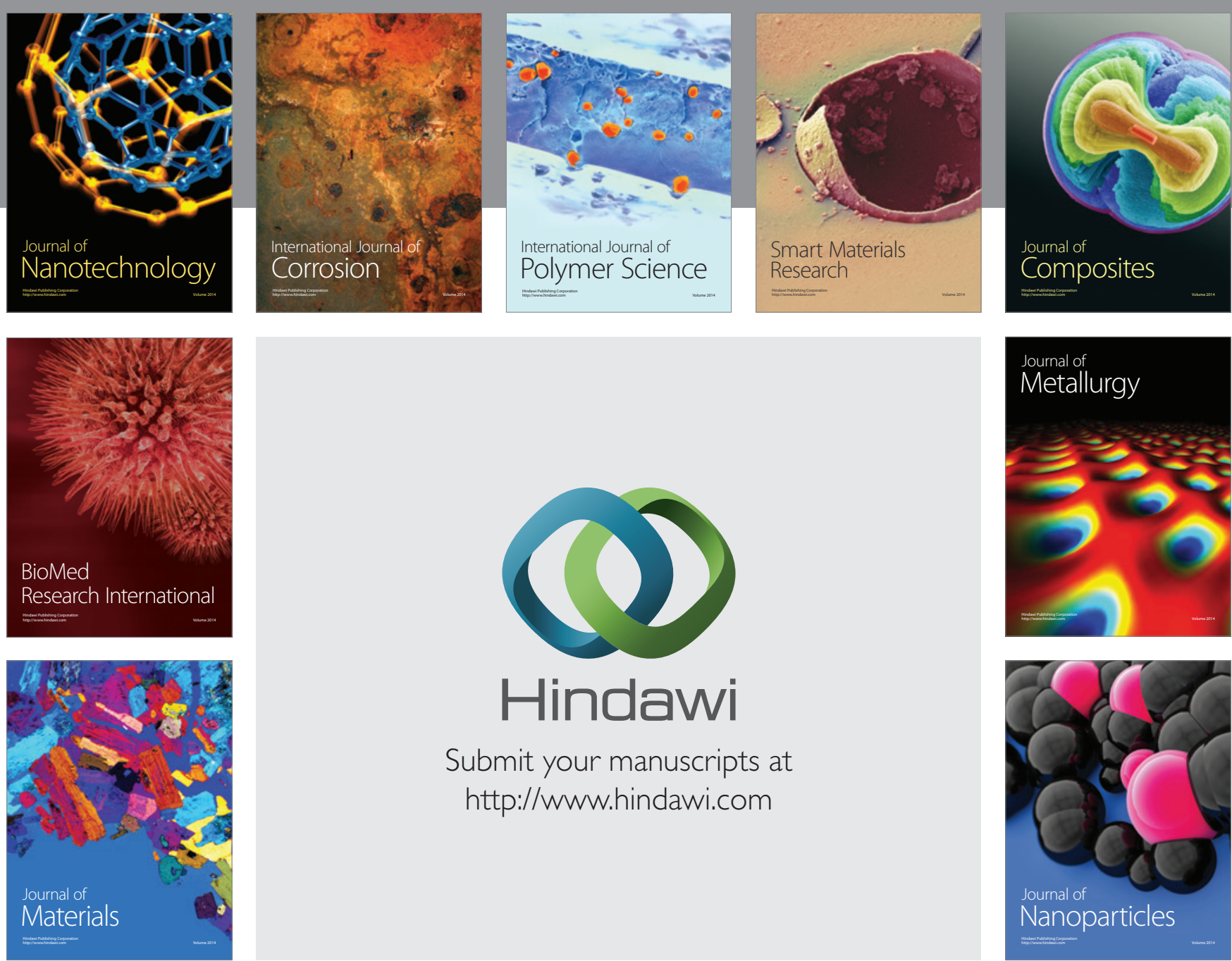

\section{Hindawi}

Submit your manuscripts at

http://www.hindawi.com

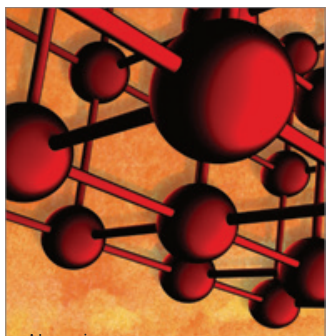

Materials Science and Engineering
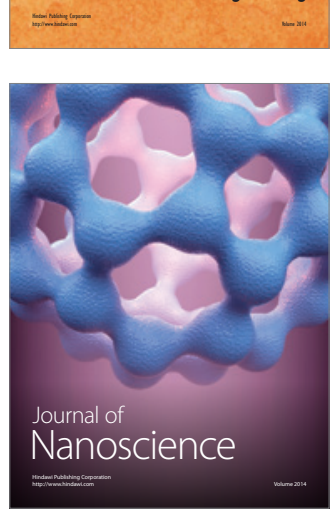
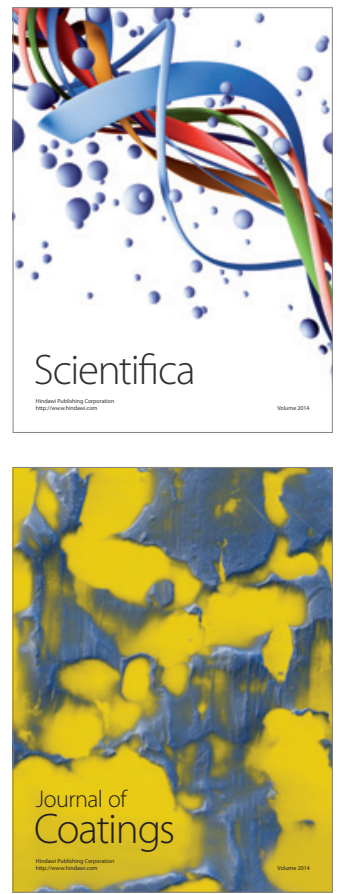
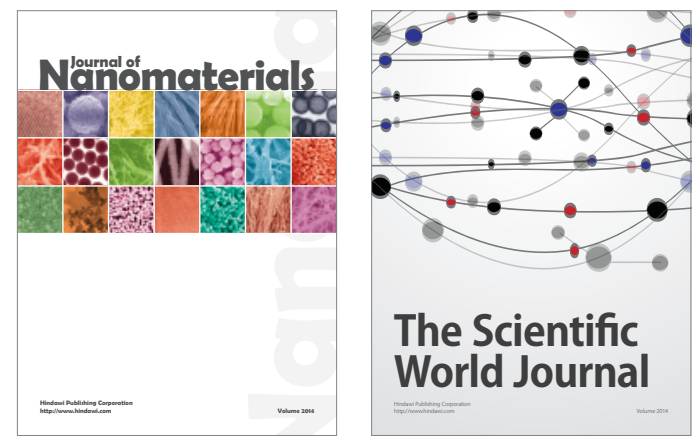

The Scientific World Journal
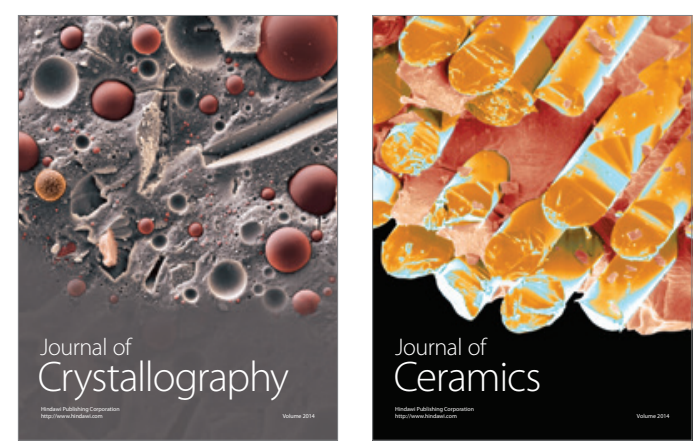
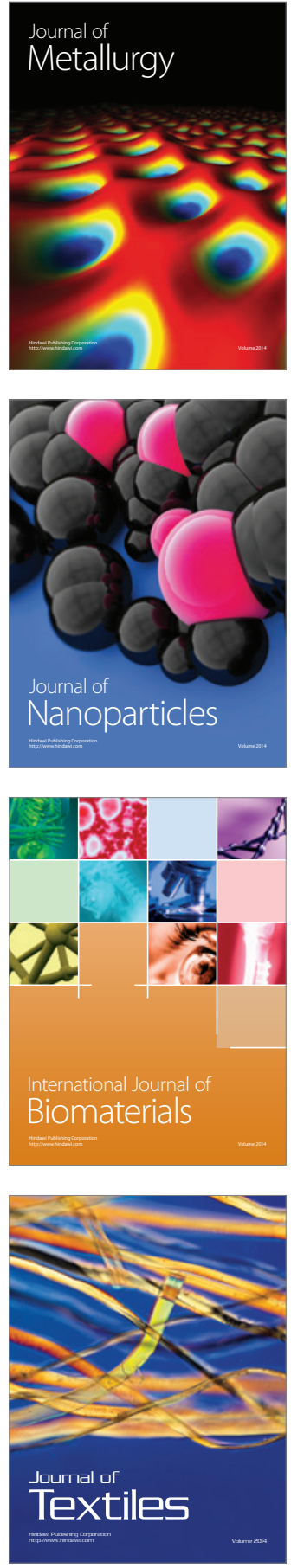